\title{
Applications of Hyaluronic Acid in Ophthalmology and Contact Lenses
}

\author{
Wan-Hsin Chang ${ }^{1}$, Pei-Yi Liu ${ }^{1}$, Min-Hsuan Lin ${ }^{1}$, Chien-Ju Lu ${ }^{1}$, Hsuan-Yi Chou ${ }^{1}$, Chih-Yu Nian ${ }^{1}$, \\ Yuan-Ting Jiang ${ }^{1, *}$ and Yuan-Hao Howard Hsu ${ }^{2, *(\mathbb{D})}$
}

1 Research and Development Center, Yung Sheng Optical Company, Daya District, Taichung 42881, Taiwan; wanhsinchang@hydron.com.tw (W.-H.C.); ginaliu@hydron.com.tw (P.-Y.L.); hsuanlin@hydron.com.tw (M.-H.L.); rurulu@hydron.com.tw (C.-J.L.); nu5544@hydron.com.tw (H.-Y.C.); joseynian@hydron.com.tw (C.-Y.N.)

2 Department of Chemistry, Tunghai University, Xitun District, Taichung 40704, Taiwan

* Correspondence: johnjiang@hydron.com.tw (Y.-T.J.); howardhsu@thu.edu.tw (Y.-H.H.H.); Tel.: +886-4-25658384 (ext. 3706) (Y.-T.J.); +886-4-23590121 (ext. 32238) (Y.-H.H.H.)

Citation: Chang, W.-H.; Liu, P.-Y.; Lin, M.-H.; Lu, C.-J.; Chou, H.-Y.; Nian, C.-Y.; Jiang, Y.-T.; Hsu, Y.-H.H. Applications of Hyaluronic Acid in Ophthalmology and Contact Lenses. Molecules 2021, 26, 2485. https:// doi.org/10.3390/molecules26092485

Academic Editor: Silvia Arpicco and Barbara Stella

Received: 26 March 2021

Accepted: 19 April 2021

Published: 24 April 2021

Publisher's Note: MDPI stays neutral with regard to jurisdictional claims in published maps and institutional affiliations.

Copyright: (c) 2021 by the authors. Licensee MDPI, Basel, Switzerland. This article is an open access article distributed under the terms and conditions of the Creative Commons Attribution (CC BY) license (https:// creativecommons.org/licenses/by/ $4.0 /)$.

\begin{abstract}
Hyaluronic acid (HA) is a glycosaminoglycan that was first isolated and identified from the vitreous body of a bull's eye. HA is ubiquitous in the soft connective tissues of animals and therefore has high tissue compatibility for use in medication. Because of HA's biological safety and water retention properties, it has many ophthalmology-related applications, such as in intravitreal injection, dry eye treatment, and contact lenses. Due to its broad range of applications, the identification and quantification of HA is a critical topic. This review article discusses current methods for analyzing HA. Contact lenses have become a widely used medical device, with HA commonly used as an additive to their production material, surface coating, and multipurpose solution. HA molecules on contact lenses retain moisture and increase the wearer's comfort. HA absorbed by contact lenses can also gradually release to the anterior segment of the eyes to treat dry eye. This review discusses applications of HA in ophthalmology.
\end{abstract}

Keywords: hyaluronic acid; contact lenses; ophthalmology

\section{Introduction}

Hyaluronic acid (HA) is a natural high-molecular-weight biopolymer. It belongs to the group of long linear nonsulfated glycosaminoglycans (GAGs) with repeating disaccharide units of glucuronic acid and acetylglucosamine [1-3] (Figure 1). HA contains multiple hydrophilic functional groups, including carboxyl, hydroxyl, and acetamido groups [4,5]. The abundant hydroxyl groups form a hydrogen bond with water, leading to a high capacity to retain water in a spiral chain [6]. HA's biocompatibility is because of its high structural homology with endogenous HA in humans [7]. When dissolved in aqueous solution, HA swells and the chains of HA entangle and become random coils, leading to its unique viscoelasticity $[6,8,9]$. Because of its advantageous characteristics, such as high water retention, high biocompatibility, and viscoelasticity [10], HA has a wide range of applications for medicine, aesthetic medicine, and cosmetics.

Various biological functions of HA are related to its level of polymerization. Highmolecular-weight HA ( $\left.\geq 10^{6} \mathrm{Da}\right)$ inhibits inflammation through its interaction with the cluster of differentiation 44 (CD44) cell surface receptor and the HA-mediated motility receptor [4,11]. High-molecular-weight HA can also form a film on the skin's surface that retains water and prevents water loss [1,12]. Conversely, low-molecular-weight HA $\left(<10^{6} \mathrm{Da}\right)$ promotes the macrophage inflammatory process by macrophage activation to remove infectious materials from the wound site $[4,13]$. Low-molecular-weight HA has a high capacity to penetrate skin that ensures a strong moisturizing ability $[1,12]$. Reducing the molecular weight of high-molecular-weight HA through physical or chemical 
methods can increase HA's potential applications. Physical pretreatment methods, such as ultrasonic degradation [14,15], ozone treatment [16], electron beam [17], gamma ray [13] or microwave irradiation, and thermal treatment [17], do not destroy the chemical structure of HA. However, chemical methods such as enzymatic [18] and acid degradation [15] break the structure of HA.

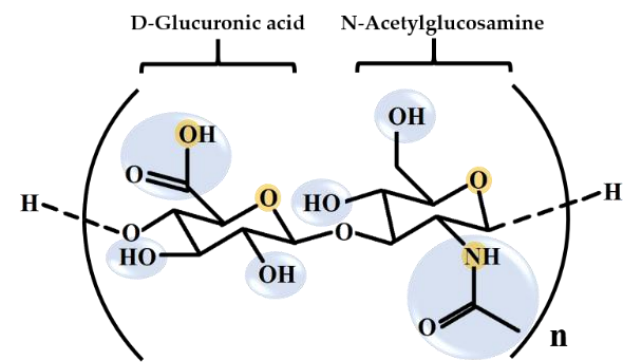

Hydrophilic groups Atoms can form hydrogen bonds

Figure 1. Chemical structure of hyaluronic acid.

HA is synthesized in humans by HA synthases, including hyaluronan synthase 1 , hyaluronan synthase 2 , and hyaluronan synthase 3 , mostly present in the extracellular matrix of vertebrate tissue $[4,5,19]$. HA is present in the umbilical cord $(4100 \mu \mathrm{g} / \mathrm{g})$, synovial fluid (1400-3600 $\mu \mathrm{g} / \mathrm{g})$, dermis (200 $\mu \mathrm{g} / \mathrm{g})$, vitreous body (140-338 $\mu \mathrm{g} / \mathrm{g})$, and brain (35-115 $\mu \mathrm{g} / \mathrm{g}$ ) [20-23]. HA was originally extracted from animal tissue [4,24,25], but the process is tedious and complicated and the quality uncontrollable, with potentially low yield and a risk of protein and virus pollution [6,26]. Microbial fermentation has been widely used to produce HA but the safety and compatibility with the human body of such HA is of the utmost concern [4,6,24-26]. Numerous toxicity assays of HA have demonstrated that in terms of cytotoxicity, L929 mouse fibroblast cells have no toxic effect [7, 27-29]. The carcinogenicity of HA was tested by the mouse, and no tumor growth was observed after delivered through oral administration of $200 \mathrm{mg}$ /day for 4 weeks [7,30,31]. Concentrations of $670 \mathrm{mg} / \mathrm{kg} /$ day HA in rats and $50 \mathrm{mg} / \mathrm{kg} /$ day HA in rats and rabbits delivered through oral administration and subcutaneous administration have exhibited no adverse effects in reproductive and developmental toxicity assays [7,31-33]. These results have demonstrated the safety of HA.

HA exhibits good versatility in application. Because it retains water well, it can be employed to increase tear film stability to treat dry eye disease [34]; it can be added to contact lens during production [35] and contact lens care solutions [36] to increase comfort; and it can be used in skin care products [37] or added to health food to reduce dry skin [38,39]. Due to its high biocompatibility, HA can enhance tissue growth to heal wounds when combined with receptors on the cell surface [13] or form dermal fillers to improve wrinkles [40]. HA's high viscoelasticity can decrease friction on the ocular surface during blinking to treat dry eye [34] and keratoconjunctivitis sicca [41] or improve synovial fluid quality and reduce joint friction in the treatment of osteoarthritis [42].

\section{HA Identification and Quantification Methods}

Despite its already numerous applications in various fields, it is necessary to properly inspect and confirm HA's physical properties, such as its structure type, molecular weight, and concentration, to determine its ideal use. HA extracted from animals and microorganisms alike requires multiple purification steps [14,43-45]. The identification and quantification of purified HA requires various pretreatments to prepare HA for further analysis, including enzymatic degradation [18,46,47], acid hydrolysis [48], labeling [48], acid digestion [49], and derivatization [46,48].

After pretreatment, the HA can be detected through traditional electrophoresis of a membrane [50] or gel $[18,44,47]$ matrix. Compared with membrane or gel electrophoresis, 
advanced capillary electrophoresis is simple, rapid, and sensitive, with high separation efficiency [51-53]. Scientists use high-performance liquid chromatography (HPLC) with ultraviolet or mass detection to analyze HA in complicated biological samples $[48,54,55]$. Although HPLC columns are expensive, this technique is effective for analyzing HA quantitatively and qualitatively with high detection sensitivity. Other analytical techniques applied to HA analysis include Fourier transform infrared spectroscopy [15-17], circular dichroism [15], ultraviolet-visible absorption spectroscopy [15-17], and nuclear magnetic resonance spectroscopy $[13,16,56]$. Quantitative and qualitative methods of analyzing HA are summarized in Table 1.

Table 1. Methods of analysis applied to hyaluronic acid (HA).

\begin{tabular}{|c|c|c|c|c|c|}
\hline Analysis Method & $\begin{array}{l}\text { Hyaluronic Acid } \\
\text { Characterization }\end{array}$ & Sample & Linear Range & LOD & Detection Range \\
\hline FTIR & 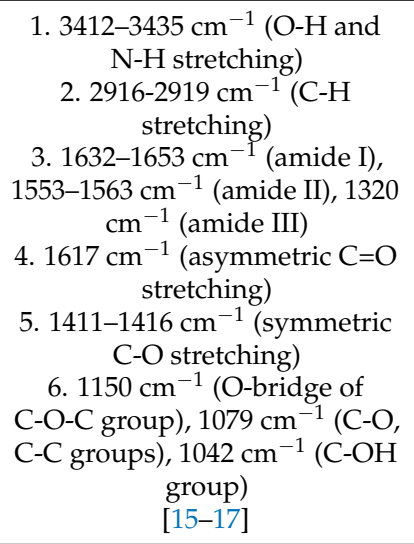 & $2 \mathrm{mg}[44,45]$ & - & - & - \\
\hline $\mathrm{CD}$ & $\begin{array}{l}\text { 1. } 183 \mathrm{~nm} \text { (carboxyl } \pi-\pi^{*} \\
\text { transition). } \\
\text { 2. } 187 \mathrm{~nm}\left(\pi-\pi^{*} \text { transition of }\right. \\
\text { GlcNAc) } \\
\text { 3. } 210 \mathrm{~nm}\left(\pi-\pi^{*} \text { transition }\right. \\
\text { carboxyl group) [15] }\end{array}$ & $0.5 \mathrm{mg} / \mathrm{mL}[15]$ & - & - & - \\
\hline UV-Vis & $\begin{array}{c}\text { 1. } \sim 210 \mathrm{~nm} \text { (carbonyl-or } \\
\text { carboxyl groups) }[43] \\
\text { 2. } 265 \mathrm{~nm} \text { (double bond) }[13,17]\end{array}$ & $0.5-2 \mathrm{mg} / \mathrm{mL}[13,15]$ & - & - & - \\
\hline NMR & $\begin{array}{c}\text { 1. } 25,57,63,71,76,79,83,85, \\
103,106,177 \mathrm{ppm}\left({ }^{13} \mathrm{C}\right)[45] \\
\text { 2. } 171 \mathrm{ppm} \text { (carboxylate } \\
\text { carbon), } 175 \mathrm{ppm}(\text { acetamido } \\
\text { carbonyl carbon }\left({ }^{13} \mathrm{C}\right)[13] \\
\text { 3. } 1.89\left(\mathrm{CH}_{3} \text {-group), } 3.70\right. \\
\left(\mathrm{CH}_{2} \text {-group), 3.69 (NH-group), }\right. \\
\text { 4.3-4.4 (OH-group) ppm } \\
\left({ }^{1} \mathrm{H}\right) \text { [56] }\end{array}$ & - & - & - & - \\
\hline Carbazole & 516 [56] or $540 \mathrm{~nm} \mathrm{[44]}$ & - & - & - & $\begin{array}{c}0.03-1.7 \mathrm{~g} / \mathrm{L}[44] \text { or } \\
6-10 \mathrm{~g} / \mathrm{L}[56]\end{array}$ \\
\hline ELISA & $450 \mathrm{~nm}[50]$ & - & - & - & $150-250 \mathrm{ng} / \mu \mathrm{g}[50]$ \\
\hline Gel EP & $\begin{array}{l}\text { 1. } 515 \mathrm{~nm} \text { (ANTS-label) [18] } \\
\text { 2. Alcian blue with silver and } \\
\text { Stains-all stain }[44,47]\end{array}$ & - & $\begin{array}{c}\sim 25-500 \mathrm{kDa} \\
{[44,47]}\end{array}$ & - & 4-20-mer [18] \\
\hline Membrane EP & $\begin{array}{l}\text { Polysaccharides in Alcian blue } \\
\text { stain [50] }\end{array}$ & - & - & - & - \\
\hline $\mathrm{CE}$ & $200 \mathrm{~nm}[51,53], 195 \mathrm{~nm}[52]$ & - & $\begin{array}{c}50-150 \text { ppm [52] } \\
\text { or } \\
0.02-3.0 \text { ppm [53] }\end{array}$ & $\begin{array}{l}1 \mathrm{ppm}[52] \\
9 \mathrm{ppm}[53]\end{array}$ & - \\
\hline
\end{tabular}


Table 1. Cont.

\begin{tabular}{|c|c|c|c|c|c|}
\hline Analysis Method & $\begin{array}{l}\text { Hyaluronic Acid } \\
\text { Characterization }\end{array}$ & Sample & Linear Range & LOD & Detection Range \\
\hline $\begin{array}{l}\text { HPLC coupled with } \\
\text { MALS }\end{array}$ & - & $0.05-0.1 \mathrm{mg}[14,47]$ & - & - & $\begin{array}{c}\text { 75-1000 kDa [15] } \\
\text { or } \\
510 \mathrm{kDa}[51]\end{array}$ \\
\hline $\begin{array}{l}\text { HPLC coupled with } \\
\text { VD }\end{array}$ & - & $0.1 \mathrm{mg}[14]$ & - & - & $470-1600(\mathrm{~mL} / \mathrm{g})[14]$ \\
\hline $\begin{array}{l}\text { HPLC coupled with } \\
\text { RID }\end{array}$ & - & $0.1-2 \mathrm{mg}[13,14,43]$ & $\begin{array}{c}270-2000 \mathrm{kDa} \\
{[43]}\end{array}$ & - & $\begin{array}{l}60-23,000 \mathrm{kDa}[13] \\
\text { or } \\
180-1100 \mathrm{kDa}[14]\end{array}$ \\
\hline $\begin{array}{l}\text { HPLC coupled with } \\
\text { FL }\end{array}$ & $\begin{array}{c}\lambda \mathrm{ex}=428 \mathrm{~nm}, \lambda \mathrm{em}=525 \mathrm{~nm} \\
{[46]}\end{array}$ & - & $1.6-47 \mu \mathrm{g}[46]$ & $2.7 \mathrm{ng}[46]$ & - \\
\hline $\begin{array}{l}\text { HPLC coupled with } \\
\text { MS }\end{array}$ & $\begin{array}{c}\text { Positive ionization mode }[48,49] \\
\text { Negative ionization mode } \\
{[46,54]}\end{array}$ & - & $\begin{array}{c}0.5-500 \mathrm{pmol}[54] \\
\text { or } \\
0.01-1.0 \mathrm{mg} / \mathrm{mL} \\
{[48]}\end{array}$ & $\begin{array}{l}0.6 \mathrm{~g} / \mathrm{mL}[49] \\
0.1 \mathrm{ppm}[48]\end{array}$ & - \\
\hline $\begin{array}{l}\text { HPLC coupled with } \\
\text { UV }\end{array}$ & $205 \mathrm{~nm}$ [55] & - & $\begin{array}{c}0.01-0.15 \mathrm{mg} / \mathrm{mL} \\
{[55]}\end{array}$ & 0.45 ppm [55] & - \\
\hline
\end{tabular}

Analysis instrument abbreviations: Fourier transform infrared spectroscopy (FTIR), circular dichroism (CD), ultraviolet-visible absorption spectrum (UV-Vis), nuclear magnetic resonance spectroscopy (NMR), enzyme-linked immunosorbent assay (ELISA), electrophoresis (EP), 8-aminonaphthalene-1,3,6-trisulfonic acid (ANTS), capillary electrophoresis (CE), high-performance liquid chromatography (HPLC), multi-angle light scattering (MALS), viscometer detector (VD), refractive index detector (RID), fluorescence (FL), excitation wavelength $(\lambda e x)$, emission wavelength ( $\lambda$ em), and mass spectrometry (MS). The limit of detection abbreviation is LOD.

Agarose gel electrophoresis [44], HPLC with a refractive index detector $[13,14,43]$, or a multi-angle light scattering detector $[15,47,51]$ can be applied to identify the molecular weight of HA after extraction from animals, microbial production, or degradation. To reconfirm HA's molecular weight, HPLC with a viscometer detector and multi-angle light scattering detector can used to detect changes in HA's viscosity and molecular radius [14]. These methods can be used to compare the antioxidant [14,43] and antiglycation activities [14] of HA of various molecular weights, identify HA in mouse plasma [51], and prepare low-molecular-weight HA [15,47] to promote skin wound healing [13].

HA quantitation can be performed through a carbazole method $[44,56]$, enzymelinked immunosorbent assay [50], capillary electrophoresis [51-53], or HPLC, coupled with triple quadrupole mass spectrometry [48], fluorescence [46], mass spectrometric detector $[49,54]$, or an ultraviolet-visible detector [55], to determine the quantification and detection limit $[46,48,49,54,55]$. The detection limit of capillary electrophoresis is 1-15 ppm [51-53]. The detection limit of HPLC coupled with fluorescence or different mass spectrometry is $2.7 \mathrm{ng}$ [46] and $0.11-4 \mathrm{ppm}[48,49]$. HPLC with an ultraviolet-visible spectrum reached a detection limit of $0.45 \mathrm{ppm}$ [55]. These methods can also be applied to verify the labeled and declared content of HA [46], quantitatively compare HA in edible fish intestines and liver [48], quickly quantify HA in biological and cosmetic products [52], quantify HA in contact lens multipurpose solution, and analyze the release behavior from contact lenses [55]. HA is also used in highly diverse and complex samples; thus, developing improved methods of sensitivity detection is vital. Although each method has its unique purpose, current HA analysis requires simple sample preparation, swift data acquisition, and high sensitivity.

\section{Applications of HA in Ophthalmology}

HA is found in various tissues in the eye, including the aqueous humor, trabecular meshwork, and vitreous body; through the cell surface glycoprotein CD44, HA can bind easily with the cell membrane [57]. HA also moisturizes the eye, increases biocompatibility, and prolongs drug residence time to enhance drug delivery [37,57-60]. These properties allow for HA's use in artificial tears, eye drops, in situ forming hydrogels, modified nanoparticles, intravitreal injections, and tissue engineering (Table 2). 


\subsection{HA in Artifical Tears and Eye Drops}

Dry eye syndrome (DES) is a common ocular disorder related to age, gender, diet, environment, disease, or surgery or occurring as a medication side effect [61-63]. HA can be added to artificial tears to enhance and extend the duration of moisture retention and therefore alleviate DES [60,64-67]. In eye drops, a high content of HA stabilizes tear films and increases conjunctival goblet cells [68]. Along with HA concentration, Kojima and colleagues reported that high-molecular-weight HA in eye drops exerts anti-inflammatory effects [69]. Hybridization of high and low-molecular-weight HA in eye drops can protect against dehydration of the corneal cell and promote wound healing [70]. A clinical study indicated that high-molecular-weight HA eye drops can be an alternative treatment for patients with severe dry eye [64].

HA can take different forms in eye drops and can be used in combination with another compound, act as a vehicle for drug delivery, or form a bifunctional peptide polymer. HA can be used with triglycerides, phospholipids, vitamin B12, coenzyme Q10, hydroxypropyl guar, antibiotics, or steroids. HA used with above compound could increase tear film thickness [71], improve oxidative stress in the conjunctival epithelium of patients with dry eye [72], sustains ocular surface [73,74], and reduce DES symptoms $[67,75,76]$. Eye drops containing HA are effective DES pharmaceutical vehicles [77]. HA can be combined with other compounds or peptides to heal wounds [41] and to sustain ocular surface lubrication [78].

\subsection{In Situ Forming Hydrogel}

Ointment is a more viscous topical treatment than eye drops and increases the residence time on the ocular surface to enhance drug absorption, although blurred vision is an unwelcome side effect [79]. In situ gel has the advantages of both an aqueous solution and an ointment. In situ gel is thermosensitive; it is an aqueous solution at low temperature and, as temperature rises, becomes gelatinous. High viscosity prolongs ocular residence time, which is a convenient property for ophthalmologic use [79-81]. HA is a natural polysaccharide with viscous properties, and it can be used to adjust in situ gel viscosity and degradation time [57,79-83].

Fungal keratitis, a type of cornea infection caused by a fungus, can lead to blindness [84]. Hydrophobic ketoconazole is an effective treatment for fungal keratitis, but has low solubility in aqueous solutions. Zhu and coworkers developed an in situ gel utilizing poly(N-isopropylacrylamide) and HA as a vehicle for ketoconazole. To improve biocompatibility and ocular surface residence time, in situ gel with HA was used to prolong drug release, with no irritant reaction exhibited in the rabbit eye tests. As well as creating a more viscous gel, HA can increase the lower critical solution temperature to body temperature for ease of use [79]. The sol-gel temperature also depends on HA concentration [83]. Researchers have demonstrated that in situ gel aids drug absorption and drug delivery $[80,81]$ and improves eye comfort [82].

\subsection{HA-Modified Nanoparticles}

Using nanoparticles (NPs) is a practicable method to increase drug absorption. NPs can be used as drug carriers for hydrophobic or unstable drugs. NPs interact with the corneal epithelium and enter corneal cells to decrease drug degradation $[57,85]$. After modification by HA, the use of NPs leverages such advantages as improved lubrication, long ocular residence time, and enhanced drug absorption $[85,86]$. Additionally, $\mathrm{HA}$ is prone to bind with the cellular receptor CD44, rendering HA-NPs a suitable vector for gene therapy [57].

Huang and coworkers used HA to modify gelatin loaded with epigallocatechin gallate (GEH), a green tea polyphenol that can decrease inflammation on the ocular surface [87]. The modified gelatin NPs were added to eye drops to improve DES in rabbits. HA increases the concentration of NPs on the cornea to enhance drug absorption. Following 3 weeks of topical administration, clinical tests indicated that GEH reduced inflammatory cytokines 
(tumor necrosis factor alpha, interleukin 6, interleukin 1 beta and interleukin 8) in the cornea and improved dry eye symptoms [85].

An HA-NP eye drop for glaucoma can achieve the drug absorption effect too. Patients with glaucoma experience high intraocular pressure leading to optic atrophy, whereby peripheral vision is gradually lost, eventually resulting in blindness [88,89]. Treatment for glaucoma has low bioavailability and drug retention time, with more frequent administration leading to adverse effects. Wadhwa and colleagues used HA-modified chitosan (a biodegradable polysaccharide) nanoparticles (CS-HA-NPs) loaded with medicine to improve drug retention time and reduce side effects from frequent administration [89].

Poly(lactic-co-glycolic) acid NPs coated with HA were applied to encapsulate lutein to treat age-related macular degeneration [90]. Because the macula contains high concentrations of lutein to protect photoreceptor and retinal pigment epithelium cells, properly suppling lutein prevents this degeneration [91]. Lutein is hydrophobic and easily degraded by light and heat, but NPs can enhance its bioavailability, physical stability, and decrease degradation. Furthermore, after modification of NPs with HA, HA-NPs can deliver lutein without difficulty due to binding with CD44 [90].

Nanomicelle is a surfactant that can easily encapsulate hydrophobic drug that cannot formulate in solution, but the toxicity and irritation to eye structure are disadvantages [92,93]. HA can prolong the drug duration time and increase the bioavailability to protect cornea from the toxicity and irritation caused by surfactant. Terreni, E. and coworkers used HA to modified nanomicelle to prolong drug resident time and decrease surfactant toxicity [94].

\subsection{HA Application in Intravitreal Injections}

Intravitreal injections can be used for the administration of drugs, gene therapy, or the artificial vitreous humor. These injections can break through barriers that affect drug absorption such as corneal tissue, tear flushing, tear secretions, or drug delivery to target area located in the posterior eye $[95,96]$. Disadvantages of intravitreal injection include an increase of intraocular pressure and the necessity of repeated injections due to rapid drug release [96,97]. These drawbacks are burdens on the patient and may induce complications [98-100]. The high biocompatibility, biodegradability, and capacity to prolong drug release of HA make it ideal as an artificial vitreous material or intravitreal injection drug component.

Drug intravitreal injections are widely used in ophthalmology, but the short-lived effect of the drugs results in a need for repeated injections, which can cause side effects. Yu and coworkers encapsulated bevacizumab, a treatment for ocular neovascularization, into a hydrogel mixed with HA and dextran to slow drug release. The results demonstrated that the gel was highly biocompatible, facilitated a more stable release of drugs compared with a bolus injection, and could sustain drug effects for more than 6 months [99]. NPs can also be administered through intravitreal injection [101-103]. NPs protect drugs from degradation, extend the drug releasing duration, and reduce the frequency with which injections must be administered. After modification with HA, NPs can effectively combine with the affected cell through the binding of HA and CD44. Connexins, a 43-kDa mimetic peptide, was loaded into HA-NPs to treat retinal disease, and their injection into Wistar rats' injured eyes improved drug duration and cell uptake [102].

Gene therapy uses intravitreal injection to break through barriers and reach the target area [95]. The eye is suitable for gene therapy because of its immune privilege- the inflammatory immune response is avoided to preserve its function [104,105]. Martens and coworkers used cationic $N, N^{\prime}$-cystaminebisacrylamide-4-aminobutanol modified with HA as a vehicle loaded with anionic plasmid DNA for gene therapy. HA enhanced the connection between vehicle and target cells (ARPE-19) by binding to CD44. The researchers reported that low-molecular-weight HA can enhance the intravitreal injection of gene therapy [95].

HA is a vitreous humor component and can therefore be used for artificial vitreous humor $[106,107]$. HA can replace the silicone oil in vitrectomy and prevent side effects, 
cytotoxicity, silicone oil emulsification, or second surgery because of its biocompatibility and biodegradability [108]. Raia and colleagues combined HA and silk fibroin through enzymatic crosslinking, using horseradish peroxidase and hydrogen peroxide to increase stability. Their study demonstrated that silk-HA hydrogel possesses biocompatibility and stability as a vitreous substitute [106].

\subsection{Tissue Engineering}

HA is a critical component in the extracellular matrix. The extracellular matrix assists in cell migration, adhesion, and the proliferation $[109,110]$ of such cells as adipose-derived stem cells and limbal epithelial stem cells [111,112]. These cells aid in corneal regeneration; specifically, by making a tissue-adhesive scaffold, corneal wound healing can be promoted [113]. Because of HA's capacity for promoting cell growth and wound healing, Liu and coworkers crosslinked collagen and gelatin with HA to fabricate a film. An optimized ratio of HA, collagen, and gelatin has better tensile strength, elongation strength, water absorption, and contact angle. The morphology and methylthiazol tetrazolium assay demonstrated the growth and proliferation of human corneal epithelium cells, demonstrating that collagen-gelatin-HA (ratio 6:3:1) has appropriate biocompatibility for tissue engineering [110]. HA hydrogel can also be used in corneal tissue engineering. Overrunprocessed porous HA hydrogels act as cell carriers for corneal endothelium cells and can reconstruct the corneal endothelium. HA hydrogels exhibit biocompatibility with rabbit corneal endothelium cells. In in vivo transplant tests, HA hydrogels were implanted into the anterior chamber of an injured rabbit eye. The results indicated a significant increase in endothelium cells after 4 weeks of treatment. The slit-lamp biomicroscopic image also revealed a transparent cornea [114], indicating that the HA hydrogel had successfully reconstructed the injured cornea. These results demonstrate that HA can be a scaffold for tissue engineering.

Table 2. Applications of HA in Ophthalmology.

\begin{tabular}{|c|c|c|}
\hline Ophthalmology Application & Target & HA Function \\
\hline Artificial tear and eye drop & Ocular surface & $\begin{array}{l}\text { 1. Increase the moisture retention }[60,64-67] \\
\text { 2. Better tear film stability, ocular surface regularity, and quantity of } \\
\text { conjunctival goblet cells }[68] \\
\text { 3. Anti-inflammatory effect }[64,69] \\
\text { 4. Protect corneal cell dehydration }[70] \\
\text { 5. Increase tear film thickness }[71] \\
\text { 6. Improve dry eye patients' conjunctival epithelium oxidative stress [72] } \\
\text { 7. Have more effective treatment }[73] \\
\text { 8. To reduce the DES symptom }[67,75,76] \\
\text { 9. As DES pharmaceutical vehicle }[77] \\
\text { 10. Heal wound }[41,70] \\
\text { 11. Sustain ocular surface lubricated }[74,78]\end{array}$ \\
\hline In situ gel & Ocular surface & $\begin{array}{l}\text { 1. Adjust the viscosity and degradation time }[57,79-83] \\
\text { 2. Increase the lower critical solution temperature for thermosensitive in } \\
\text { situ gel [79] } \\
\text { 3. Help the drug absorption and drug delivery }[80,81] \\
\text { 4. Provide better eye comfort }[82]\end{array}$ \\
\hline Nanoparticles & $\begin{array}{c}\text { Ocular surface and } \\
\text { Retinal }\end{array}$ & $\begin{array}{l}\text { 1. Better lubricating, ocular residence time, and drug absorption } \\
\qquad[85,86,89,90] \\
\text { 2. Increase mucoadhesion }[89] \\
\text { 3. Increase cellular targeting by CD } 44[57,89,90] \\
\text { 4. Decrease surfactant toxicity }[94]\end{array}$ \\
\hline Intravitreal injection & Vitreous humor & $\begin{array}{l}\text { 1. Increase cellular targeting by CD44 }[95,102] \\
\text { 2. Biocompatibility and biodegradable for vitreous humor substitute } \\
\qquad[100,106-108]\end{array}$ \\
\hline Tissue engineering & Corneal & 1. Benefit of cell growth and wound healing $[110,114]$ \\
\hline
\end{tabular}




\section{Applications of HA on Contact Lenses}

HA is biocompatible and effective at retaining moisture on contact lens. HA has been applied in the contact lens field for almost 20 years, and the applications of HA include incorporation into the lenses, surface modification, multipurpose solution supplementation, stabilization of eye medication, and drug release sustainment (Table 3).

\subsection{HA-Modified Contact Lenses Exhibit Enhanced Comfort}

Contact lenses are divided into two classes based on their material, namely, hydrogel and silicon hydrogel lenses. Silicon hydrogel contact lenses have better oxygen permeability, but their hydrophobic characteristics may irritate eyes. When contact lenses soaked in multipurpose solution absorb HA, HA can decrease the surface roughness of the lens [115]. HA-modified contact lenses exhibit enhanced surface water retention [116], reduce protein adsorption $[117,118]$, and slow tear removal, which considerably increases comfort. Moreover, the surfaces of contact lenses are coated with HA to enhance its biocompatibility with human corneal epithelial cells [119].

\subsection{HA Adsorption and Desorption on Contact Lenses}

Because wearing contact lenses for prolonged periods may cause dry eye, HA-soaked contact lenses retain moisture, thus solving this problem. In our previous study, we demonstrated that contact lenses soaked in a higher-concentration HA solution released more $\mathrm{HA}$, although most HA was rapidly released in the first $30 \mathrm{~min}$. When immersed in the same concentration of HA solution, methafilcon A food and drug administration, (FDA), Group IV, high water content, ionic polymer) contact lenses demonstrated the highest attachment ability, and the polymacon (FDA Group I, low water content, nonionic polymer) demonstrated the slowest release rate [55]. Scheuer and colleagues revealed that soaking lenses in multipurpose solution containing HA overnight can promote retention of HA on the lenses and that different contact lens materials that include hydrogel (four group, including low/high water content and nonionic/ionic polymer) and silicon hydrogel have different HA release rates [120]. Absorbed HA on contact lenses is typically released in the first 2-3 h [121,122].

\subsection{HA Release on Contact Lenses}

The treatment of ocular diseases usually involves the administration of eye drop medicine to the anterior eye, but this method requires application several times a day and is burdensome to older patients or those with chronic disease. According to researchers, approximately $5 \%$ of drugs reach the cornea through this administration method [7]. Because contact lenses are widely used, convenient, and inexpensive, they can act as the medical delivery vehicle of continuous-release drugs. The incorporation of HA into contact lenses not only aids the treatment of dry eye but also serves as a wetting or comfort agent.

$\mathrm{HA}$ is the foremost molecule in the treatment of dry eye through contact lenses. The release rate of HA on HA-soaked contact lens is rapid in the first $6 \mathrm{~h}$ and then slows [123]. HA incorporated into contact lenses can be continuously released for $48 \mathrm{~h}$ [124]. Although a higher HA concentration has a relatively high initial release percentage, an increase in HA concentration does not extend release time duration [123]. For HA-laden contact lenses that entrap HA to prolong release duration [125], the HA release time was up to 15 days in a rabbit tear fluid test [123]. A molecular imprinting technique controls the release of HA from hydrogel contact lenses at the rate of $6 \mu \mathrm{g} / \mathrm{h}$ for $24 \mathrm{~h}$ [126].

In regards to HA as a wetting or comfort agent applicate to contact lenses, Weeks and coworkers reported that HA incorporated into hydrogel and silicone hydrogel contact lenses continuously released HA for at least 3 weeks [127]. HA or drugs can be implanted into contact lenses to avoid changing lens properties. HA is used as a comfort agent with various antibiotic and glaucoma drug treatments to make patient wear more comfortable. Contact lenses implanted with HA can sustain the release of HA up to $96 \mathrm{~h}$ to achieve healing effects [128-130]. 


\subsection{Application of HA in Medical Lenses}

HA assists in controlled drug release on contact lenses. Nguyen and coworkers fashioned contact lens discs containing HA and drugs. Contact lenses containing HA incorporate and release more of the drug, especially hydrophobic drugs, for 6 days [131]. $\mathrm{HA}$ is also used as an additive to hold timolol, a drug for the treatment of glaucoma. When silicon hydrogel contact lenses were loaded with HA, the drug quantity on the lens increased as did the release by approximately 2 days [132]. HA can be prepared as a film to coat contact lenses and to temporarily adhere to cells, whose viability can then be maintained to repair corneal damage [133].

Table 3. Applications of HA on Contact Lens.

\begin{tabular}{|c|c|c|c|}
\hline Application & HA Attach Contact Lens Manner & Release Time & Other Drugs \\
\hline Comfortability & Surface modification & - & - \\
\hline Moisturization & Immerse in HA-contain solution & - & - \\
\hline molecule of treatment dry eye & \multirow{3}{*}{$\begin{array}{l}\text { Immerse contact lens in } \\
\text { HA-contain drug solution or } \\
\text { incorporate in contact lens }\end{array}$} & $\begin{array}{c}24 \mathrm{~h}(6 \mu \mathrm{g} / \mathrm{h})[126], 48 \mathrm{~h} \mathrm{[124]} \text { and } \\
96 \mathrm{~h}[125], 15 \text { days [123] }\end{array}$ & - \\
\hline Wetting or comfort agent & & $\begin{array}{l}96 \mathrm{~h} \text { [128] and at least } 3 \text { weeks } \\
\text { [127] }\end{array}$ & $\begin{array}{l}\text { Timolol }[128,130] \\
\text { Bimatoprost [130] }\end{array}$ \\
\hline Drug release control & & 2 [132] and 6 [131] days & $\begin{array}{c}\text { Ciprofloxacin- } \mathrm{HCl} \text { and } \\
\text { dexamethasone phosphate [131] } \\
\text { Timolol [132] }\end{array}$ \\
\hline $\begin{array}{l}\text { Cell adhesion for corneal } \\
\text { damage repair }\end{array}$ & $\begin{array}{l}\text { HA-contain film coating in } \\
\text { contact lens inner surface }\end{array}$ & - & - \\
\hline
\end{tabular}

\section{Conclusions}

HA reveals outstanding properties of hydrophilic, safety, compatibility, and special viscoelasticity. It has been widely used in the field of ophthalmology. The applications of HA in artificial tear and eye drop, in situ gel, nanoparticles, intravitreal injection, and tissue engineering enhance eye comfortable and cure eye diseases. Moreover, HA applied in contact lenses can improve wearing comfort, control drug release, and even be the molecule to treat eye-related disease. Because HA is a macromolecule with flexible molecular weight, manufacturing specific sizes of HA molecules may enhance the stability in the versatile application. In the future, chemical medication of HA can further change the properties to adapt the applications in the medical field. More importantly, HA is also a biodegradable material, which can be used without increasing the burden to the environment.

Author Contributions: This paper is divided into four sections, each of which received contributions from all coauthors. Conceptualization, Y.-H.H.H.; writing-review and editing, W.-H.C. and Y.-T.J.; writing-original draft of Section 1, P.-Y.L. and M.-H.L.; writing-original draft of Section 2, C.-J.L.; writing-original draft of Section 3, H.-Y.C. and C.-Y.N.; writing-original draft of Section 4, W.-H.C. All authors have read and agreed to the published version of the manuscript.

Funding: This research was funded by Yung Sheng Optical Co., Ltd.

Institutional Review Board Statement: Not applicable.

Informed Consent Statement: Not applicable.

Data Availability Statement: Not applicable.

Conflicts of Interest: The authors declare no conflict of interest.

Sample Availability: Not applicable.

\section{References}

1. Essendoubi, M.; Gobinet, C.; Reynaud, R.; Angiboust, J.F.; Manfait, M.; Piot, O. Human skin penetration of hyaluronic acid of different molecular weights as probed by Raman spectroscopy. Skin Res. Technol. 2016, 22, 55-62. [CrossRef] 
2. Salwowska, N.M.; Bebenek, K.A.; Żądło, D.A.; Wcisło-Dziadecka, D.L. Physiochemical properties and application of hyaluronic acid: A systematic review. J. Cosmet. Dermatol. 2016, 15, 520-526. [CrossRef]

3. Li, J.; Qiao, M.; Ji, Y.; Lin, L.; Zhang, X.; Linhardt, R.J. Chemical, enzymatic and biological synthesis of hyaluronic acids. Int. J. Biol. Macromol. 2020, 152, 199-206. [CrossRef]

4. Fallacara, A.; Baldini, E.; Manfredini, S.; Vertuani, S. Hyaluronic Acid in the Third Millennium. Polymers 2018, 10, 701. [CrossRef]

5. Fakhari, A.; Berkland, C. Applications and emerging trends of hyaluronic acid in tissue engineering, as a dermal filler and in osteoarthritis treatment. Acta Biomater. 2013, 9, 7081-7092. [CrossRef] [PubMed]

6. Saranraj, P.; Naidu, M.A. Hyaluronic acid production and its applications-a review. Int. J. Pharm. Biol. Arch. $2013,4,853-859$.

7. Necas, J.; Bartpaíková, L.; Brauner, P.; Kolár, J. Hyaluronic acid (hyaluronan): A review. Vet. Med. 2008, 53, 397-411. [CrossRef]

8. Kobayashi, T.; Chanmee, T.; Itano, N. Hyaluronan: Metabolism and Function. Biomolecules 2020, 10, 1525. [CrossRef]

9. Kutálková, E.; Hrnčiřík, J.; Witasek, R.; Ingr, M. Effect of solvent and ions on the structure and dynamics of a hyaluronan molecule. Carbohydr. Polym. 2020, 234, 115919. [CrossRef]

10. Gupta, R.C.; Lall, R.; Srivastava, A.; Sinha, A. Hyaluronic Acid: Molecular Mechanisms and Therapeutic Trajectory. Front. Vet. Sci. 2019, 6, 192. [CrossRef]

11. Tavianatou, A.G.; Caon, I.; Franchi, M.; Piperigkou, Z.; Galesso, D.; Karamanos, N.K. Hyaluronan: Molecular size-dependent signaling and biological functions in inflammation and cancer. FEBS J. 2019, 286, 2883-2908. [CrossRef]

12. Mazzucco, A. Hyaluronic Acid: Evaluation of Efficacy with Different Molecular Weights. Int. J. Chem. Res. 2019, 1, 13-18. [CrossRef]

13. Huang, Y.C.; Huang, K.Y.; Lew, W.Z.; Fan, K.H.; Chang, W.J.; Huang, H.M. Gamma-Irradiation-Prepared Low Molecular Weight Hyaluronic Acid Promotes Skin Wound Healing. Polymers (Basel) 2019, 11, 1214. [CrossRef] [PubMed]

14. Hafsa, J.; Chaouch, M.A.; Charfeddine, B.; Rihouey, C.; Limem, K.; Le Cerf, D.; Rouatbi, S.; Majdoub, H. Effect of ultrasonic degradation of hyaluronic acid extracted from rooster comb on antioxidant and antiglycation activities. Pharm. Biol. 2017, 55, 156-163. [CrossRef] [PubMed]

15. Chen, H.; Qin, J.; Hu, Y. Efficient Degradation of High-Molecular-Weight Hyaluronic Acid by a Combination of Ultrasound, Hydrogen Peroxide, and Copper Ion. Molecules 2019, 24, 617. [CrossRef]

16. Wu, Y. Preparation of low-molecular-weight hyaluronic acid by ozone treatment. Carbohydr. Polym. 2012, 89, 709-712. [CrossRef]

17. Choi, J.-i.; Kim, J.-K.; Kim, J.-H.; Kweon, D.-K.; Lee, J.-W. Degradation of hyaluronic acid powder by electron beam irradiation, gamma ray irradiation, microwave irradiation and thermal treatment: A comparative study. Carbohydr. Polym. 2010, 79, 1080-1085. [CrossRef]

18. Gao, F.; Cao, M.; Yang, C.; He, Y.; Liu, Y. Preparation and characterization of hyaluronan oligosaccharides for angiogenesis study. J. Biomed. Mater. Res. B Appl. Biomater. 2006, 78, 385-392. [CrossRef]

19. Joy, R.A.; Vikkath, N.; Ariyannur, P.S. Metabolism and mechanisms of action of hyaluronan in human biology. Drug Metab. Pers. Ther. 2018, 33, 15-32. [CrossRef]

20. Laurent, U.B.G.; Laurent, T.C.; Hellsing, L.K.; Persson, L.; Hartman, M.; Lilja, K. Hyaluronan in human cerebrospinal fluid. Acta Neurol. Scand. 1996, 94, 194-206. [CrossRef]

21. Cowman, M.K.; Lee, H.-G.; Schwertfeger, K.L.; McCarthy, J.B.; Turley, E.A. The Content and Size of Hyaluronan in Biological Fluids and Tissues. Front. Immunol. 2015, 6, 261. [CrossRef]

22. Valachova, K.; Volpi, N.; Stern, R.; Šoltés, L. Hyaluronan in Medical Practice. Curr. Med. Chem. 2016, 23. [CrossRef] [PubMed]

23. Snetkov, P.; Zakharova, K.; Morozkina, S.; Olekhnovich, R.; Uspenskaya, M. Hyaluronic Acid: The Influence of Molecular Weight on Structural, Physical, Physico-Chemical, and Degradable Properties of Biopolymer. Polymers 2020, 12, 1800. [CrossRef] [PubMed]

24. Sze, J.H.; Brownlie, J.C.; Love, C.A. Biotechnological production of hyaluronic acid: A mini review. 3 Biotech. 2016, 6, 67. [CrossRef] [PubMed]

25. de Oliveira, J.D.; Carvalho, L.S.; Gomes, A.M.V.; Queiroz, L.R.; Magalhães, B.S.; Parachin, N.S. Genetic basis for hyper production of hyaluronic acid in natural and engineered microorganisms. Microb. Cell Factories 2016, 15, 119. [CrossRef]

26. Boeriu, C.G.; Springer, J.; Kooy, F.K.; van den Broek, L.A.M.; Eggink, G. Production Methods for Hyaluronan. Int. J. Carbohydr. Chem. 2013, 2013, 624967. [CrossRef]

27. Kim, J.-T.; Lee, D.Y.; Kim, T.-H.; Song, Y.-S.; Cho, N.-I. Biocompatibility of hyaluronic acid hydrogels prepared by porous hyaluronic acid microbeads. Met. Mater. Int. 2014, 20, 555-563. [CrossRef]

28. Mayol, L.; De Stefano, D.; De Falco, F.; Carnuccio, R.; Maiuri, M.C.; De Rosa, G. Effect of hyaluronic acid on the thermogelation and biocompatibility of its blends with methyl cellulose. Carbohydr. Polym. 2014, 112, 480-485. [CrossRef]

29. Gedikli, S.; Güngör, G.; Toptaş, Y.; Sezgin, D.E.; Demirbilek, M.; Yazıhan, N.; Aytar Çelik, P.; Denkbaş, E.B.; Bütün, V.; Çabuk, A. Optimization of hyaluronic acid production and its cytotoxicity and degradability characteristics. Prep. Biochem. Biotechnol. 2018, 48, 610-618. [CrossRef]

30. Seino, S.; Takeshita, F.; Asari, A.; Masuda, Y.; Kunou, M.; Ochiya, T. No Influence of Exogenous Hyaluronan on the Behavior of Human Cancer Cells or Endothelial Cell Capillary Formation. J. Food Sci. 2014, 79, T1469-T1475. [CrossRef]

31. Oe, M.; Tashiro, T.; Yoshida, H.; Nishiyama, H.; Masuda, Y.; Maruyama, K.; Koikeda, T.; Maruya, R.; Fukui, N. Oral hyaluronan relieves knee pain: A review. Nutr. J. 2016, 15, 11. [CrossRef] 
32. Becker, L.C.; Bergfeld, W.F.; Belsito, D.V.; Klaassen, C.D.; Marks, J.G.; Shank, R.C.; Slaga, T.J.; Snyder, P.W.; Cosmetic Ingredient Review Expert Panel, W.D.C.; Andersen, F.A. Final Report of the Safety Assessment of Hyaluronic Acid, Potassium Hyaluronate, and Sodium Hyaluronate. Int. J. Toxicol. 2009, 28, 5-67. [CrossRef]

33. Oe, M.; Mitsugi, K.; Odanaka, W.; Yoshida, H.; Matsuoka, R.; Seino, S.; Kanemitsu, T.; Masuda, Y. Dietary Hyaluronic Acid Migrates into the Skin of Rats. Sci. World J. 2014, 2014, 378024. [CrossRef]

34. Huynh, A.; Priefer, R. Hyaluronic acid applications in ophthalmology, rheumatology, and dermatology. Carbohydr. Res. 2020, 489, 107950. [CrossRef]

35. Korogiannaki, M.; Jones, L.; Sheardown, H. Impact of a Hyaluronic Acid-Grafted Layer on the Surface Properties of Model Silicone Hydrogel Contact Lenses. Langmuir 2019, 35, 950-961. [CrossRef]

36. Yamasaki, K.; Drolle, E.; Nakagawa, H.; Hisamura, R.; Ngo, W.; Jones, L. Impact of a low molecular weight hyaluronic acid derivative on contact lens wettability. Cont. Lens Anterior Eye 2020, 101334. [CrossRef]

37. Vasvani, S.; Kulkarni, P.; Rawtani, D. Hyaluronic acid: A review on its biology, aspects of drug delivery, route of administrations and a special emphasis on its approved marketed products and recent clinical studies. Int. J. Biol. Macromol. 2020, 151, 1012-1029. [CrossRef]

38. Kawada, C.; Yoshida, T.; Yoshida, H.; Matsuoka, R.; Sakamoto, W.; Odanaka, W.; Sato, T.; Yamasaki, T.; Kanemitsu, T.; Masuda, Y.; et al. Ingested hyaluronan moisturizes dry skin. Nutr. J. 2014, 13, 70. [CrossRef]

39. Kimura, M.; Maeshima, T.; Kubota, T.; Kurihara, H.; Masuda, Y.; Nomura, Y. Absorption of Orally Administered Hyaluronan. J. Med. Food 2016, 19, 1172-1179. [CrossRef]

40. Bukhari, S.N.A.; Roswandi, N.L.; Waqas, M.; Habib, H.; Hussain, F.; Khan, S.; Sohail, M.; Ramli, N.A.; Thu, H.E.; Hussain, Z. Hyaluronic acid, a promising skin rejuvenating biomedicine: A review of recent updates and pre-clinical and clinical investigations on cosmetic and nutricosmetic effects. Int. J. Biol. Macromol. 2018, 120, 1682-1695. [CrossRef] [PubMed]

41. Fallacara, A.; Vertuani, S.; Panozzo, G.; Pecorelli, A.; Valacchi, G.; Manfredini, S. Novel Artificial Tears Containing Cross-Linked Hyaluronic Acid: An In Vitro Re-Epithelialization Study. Molecules 2017, 22, 2104. [CrossRef]

42. Bowman, S.; Awad, M.E.; Hamrick, M.W.; Hunter, M.; Fulzele, S. Recent advances in hyaluronic acid based therapy for osteoarthritis. Clin. Transl Med. 2018, 7, 6. [CrossRef] [PubMed]

43. Pan, N.C.; Pereira, H.C.B.; da Silva, M.L.C.; Vasconcelos, A.F.D.; Celligoi, M. Improvement Production of Hyaluronic Acid by Streptococcus zooepidemicus in Sugarcane Molasses. Appl. Biochem. Biotechnol. 2017, 182, 276-293. [CrossRef]

44. Chahuki, F.F.; Aminzadeh, S.; Jafarian, V.; Tabandeh, F.; Khodabandeh, M. Hyaluronic acid production enhancement via genetically modification and culture medium optimization in Lactobacillus acidophilus. Int. J. Biol. Macromol. 2019, 121, 870-881. [CrossRef] [PubMed]

45. Reddy, K.J.; Karunakaran, K.T. Purification and characterization of hyaluronic acid produced by Streptococcus zooepidemicus strain 3523-7. J. BioSci. Biotech. 2013, 2, 173-179.

46. Kašparová, J.; Arnoldová, K.; Korecká, L.; Česlová, L. Determination of hyaluronic acid in pharmaceutical products by spectrophotometry and HPLC coupled to fluorescence or mass spectrometric detection. Sci. Pap. Univ. Pardubice Ser. A. 2018, 24, 39-47.

47. Holubova, L.; Korecka, L.; Podzimek, S.; Moravcova, V.; Rotkova, J.; Ehlova, T.; Velebny, V.; Bilkova, Z. Enhanced multiparametric hyaluronan degradation for production of molar-mass-defined fragments. Carbohydr. Polym. 2014, 112, 271-276. [CrossRef]

48. Song, S.; Yu, Q.; Zhang, B.; Ai, C.; Sun, Y.; Fu, Y.; Zhao, M.; Wen, C. Quantification and comparison of acidic polysaccharides in edible fish intestines and livers using HPLC-MS/MS. Glycoconj J. 2017, 34, 625-632. [CrossRef]

49. Vigliano, M.; Bianchera, A.; Bettini, R.; Elviri, L. Determination of Hyaluronic Acid in a Chitosan-Based Formulation by RP C18 and HILIC LC-ESI-MS: An Evaluation of Matrix Effect. Chromatographia 2013, 76, 1761-1766. [CrossRef]

50. Tzellos, T.; Kyrgidis, A.; Vahtsevanos, K.; Triaridis, S.; Printza, A.; Klagas, I.; Zvintzou, E.; Kritis, A.; Karakiulakis, G.; Papakonstantinou, E. Nodular basal cell carcinoma is associated with increased hyaluronan homeostasis. J. Eur. Acad. Dermatol. Venereol. 2011, 25, 679-687. [CrossRef]

51. Zhao, T.; Song, X.; Tan, X.; Xu, L.; Yu, M.; Wang, S.; Liu, X.; Wang, F. Development of a rapid method for simultaneous separation of hyaluronic acid, chondroitin sulfate, dermatan sulfate and heparin by capillary electrophoresis. Carbohydr. Polym. 2016, 141, 197-203. [CrossRef]

52. Chindaphan, K.; Wongravee, K.; Nhujak, T.; Dissayabutra, T.; Srisa-Art, M. Online preconcentration and determination of chondroitin sulfate, dermatan sulfate and hyaluronic acid in biological and cosmetic samples using capillary electrophoresis. J. Sep. Sci. 2019, 42, 2867-2874. [CrossRef]

53. Liu, X.; Sun, C.; Zang, H.; Wang, W.; Guo, R.; Wang, F. Capillary electrophoresis for simultaneous analysis of heparin, chondroitin sulfate and hyaluronic acid and its application in preparations and synovial fluid. J. Chromatogr. Sci. 2012, 50, 373-379. [CrossRef] [PubMed]

54. Osago, H.; Shibata, T.; Hara, N.; Kuwata, S.; Kono, M.; Uchio, Y.; Tsuchiya, M. Quantitative analysis of glycosaminoglycans, chondroitin/dermatan sulfate, hyaluronic acid, heparan sulfate, and keratan sulfate by liquid chromatography-electrospray ionization-tandem mass spectrometry. Anal. Biochem. 2014, 467, 62-74. [CrossRef] [PubMed]

55. Wan-Hsin, C.; Pei-Yi, L.; Yuan-Ting Jiang and Yuan-Hao Howard, H. A Sensitive Chromatographic Method for Hyaluronate Quantification Applied to Analyze the Desorption Behavior on Contact Lenses. Curr. Pharm. Anal. 2020, 16, 782-791. [CrossRef] 
56. Güngör, G.; Gedikli, S.; Toptaş, Y.; Akgün, D.E.; Demirbilek, M.; Yazıhan, N.; Aytar Çelik, P.; Denkbaş, E.B.; Çabuk, A. Bacterial hyaluronic acid production through an alternative extraction method and its characterization. J. Chem. Technol. Biotechnol. 2019, 94, 1843-1852. [CrossRef]

57. Guter, M.; Breunig, M. Hyaluronan as a promising excipient for ocular drug delivery. Eur. J. Pharm. Biopharm. 2017, 113, 34-49. [CrossRef]

58. Zhang, H.; Huang, S.; Yang, X.; Zhai, G. Current research on hyaluronic acid-drug bioconjugates. Eur. J. Med. Chem. 2014, 86, 310-317. [CrossRef]

59. Grassiri, B.; Zambito, Y.; Bernkop-Schnürch, A. Strategies to prolong the residence time of drug delivery systems on ocular surface. Adv. Colloid Interface Sci. 2021, 288, 102342. [CrossRef]

60. Salzillo, R.; Schiraldi, C.; Corsuto, L.; D'Agostino, A.; Filosa, R.; De Rosa, M.; La Gatta, A. Optimization of hyaluronan-based eye drop formulations. Carbohydr. Polym. 2016, 153, 275-283. [CrossRef]

61. Wang, M.T.M.; Muntz, A.; Lim, J.; Kim, J.S.; Lacerda, L.; Arora, A.; Craig, J.P. Ageing and the natural history of dry eye disease: A prospective registry-based cross-sectional study. Ocul. Surf. 2020, 18, 736-741. [CrossRef]

62. The Epidemiology of Dry Eye Disease: Report of the Epidemiology Subcommittee of the International Dry Eye WorkShop (2007). Ocul. Surf. 2007, 5, 93-107. [CrossRef]

63. Valim, V.; Trevisani, V.F.M.; de Sousa, J.M.; Vilela, V.S.; Belfort, R. Current Approach to Dry Eye Disease. Clin. Rev. Allergy Immunol. 2015, 49, 288-297. [CrossRef]

64. Beck, R.; Stachs, O.; Koschmieder, A.; Mueller-Lierheim, W.G.K.; Peschel, S.; van Setten, G.B. Hyaluronic Acid as an Alternative to Autologous Human Serum Eye Drops: Initial Clinical Results with High-Molecular-Weight Hyaluronic Acid Eye Drops. Case Rep. Ophthalmol. 2019, 10, 244-255. [CrossRef] [PubMed]

65. Kaya, S.; Schmidl, D.; Schmetterer, L.; Witkowska, K.; Unterhuber, A.; Aranha, V.; Baar, C.; Garhöfer, G.; Werkmeister, R. Effect of hyaluronic acid on tear film thickness as assessed with ultra-high resolution optical coherence tomography. Acta Ophthalmol. 2015, 93, 439-443. [CrossRef]

66. Pinto-Fraga, J.; López-de la Rosa, A.; Blázquez Arauzo, F.; Urbano Rodríguez, R.; González-García, M.J. Efficacy and Safety of 0.2\% Hyaluronic Acid in the Management of Dry Eye Disease. Eye E Contact Lens 2017, 43, 57-63.

67. Mencucci, R.; Boccalini, C.; Caputo, R.; Favuzza, E. Effect of a hyaluronic acid and carboxymethylcellulose ophthalmic solution on ocular comfort and tear-film instability after cataract surgery. J. Cataract Refract. Surg. 2015, 41, 1699-1704. [CrossRef]

68. You, I.C.; Li, Y.; Jin, R.; Ahn, M.; Choi, W.; Yoon, K.C. Comparison of $0.1 \%, 0.18 \%$, and $0.3 \%$ Hyaluronic Acid Eye Drops in the Treatment of Experimental Dry Eye. J. Ocul. Pharmacol. Ther. 2018, 34, 557-564. [CrossRef]

69. Kojima, T.; Nagata, T.; Kudo, H.; Müller-Lierheim, W.G.K.; van Setten, G.-B.; Dogru, M.; Tsubota, K. The Effects of High Molecular Weight Hyaluronic Acid Eye Drop Application in Environmental Dry Eye Stress Model Mice. Int. J. Mol. Sci. 2020, $21,3516$. [CrossRef]

70. La Gatta, A.; Corsuto, L.; Salzillo, R.; D’Agostino, A.; De Rosa, M.; Bracco, A.; Schiraldi, C. In Vitro Evaluation of Hybrid Cooperative Complexes of Hyaluronic Acid as a Potential New Ophthalmic Treatment. J. Ocul. Pharmacol. Ther. 2018, 34, 677-684. [CrossRef]

71. Effect of Single Instillation of Two Hyaluronic Acid-Based Topical Lubricants on Tear Film Thickness in Patients with Dry Eye Syndrome. J. Ocul. Pharmacol. Ther. 2018, 34, 605-611. [CrossRef]

72. Macri, A.; Scanarotti, C.; Bassi, A.M.; Giuffrida, S.; Sangalli, G.; Traverso, C.E.; Iester, M. Evaluation of oxidative stress levels in the conjunctival epithelium of patients with or without dry eye, and dry eye patients treated with preservative-free hyaluronic acid $0.15 \%$ and vitamin B12 eye drops. Graefes Arch. Clin. Exp. Ophthalmol. 2015, 253, 425-430. [CrossRef]

73. Postorino, E.I.; Rania, L.; Aragona, E.; Mannucci, C.; Alibrandi, A.; Calapai, G.; Puzzolo, D.; Aragona, P. Efficacy of eyedrops containing cross-linked hyaluronic acid and coenzyme Q10 in treating patients with mild to moderate dry eye. Eur J. Ophthalmol 2018, 28, 25-31. [CrossRef]

74. Rangarajan, R.; Kraybill, B.; Ogundele, A.; Ketelson, H.A. Effects of a Hyaluronic Acid/Hydroxypropyl Guar Artificial Tear Solution on Protection, Recovery, and Lubricity in Models of Corneal Epithelium. J. Ocul. Pharmacol. Ther. 2015, 31, $491-497$. [CrossRef]

75. Caretti, L.; La Gloria Valerio, A.; Piermarocchi, R.; Badin, G.; Verzola, G.; Masarà, F.; Scalora, T.; Monterosso, C. Efficacy of carbomer sodium hyaluronate trehalose vs hyaluronic acid to improve tear film instability and ocular surface discomfort after cataract surgery. Clin. Ophthalmol. 2019, 13, 1157-1163. [CrossRef] [PubMed]

76. Favuzza, E.; Cennamo, M.; Vicchio, L.; Giansanti, F.; Mencucci, R. Protecting the Ocular Surface in Cataract Surgery: The Efficacy of the Perioperative Use of a Hydroxypropyl Guar and Hyaluronic Acid Ophthalmic Solution. Clin. Ophthalmol. 2020, 14, 1769-1775. [CrossRef]

77. Rolando, M.; Vagge, A. Safety and Efficacy of Cortisol Phosphate in Hyaluronic Acid Vehicle in the Treatment of Dry Eye in Sjogren Syndrome. J. Ocul. Pharmacol. Ther. 2017, 33, 383-390. [CrossRef] [PubMed]

78. Lee, D.; Lu, Q.; Sommerfeld, S.D.; Chan, A.; Menon, N.G.; Schmidt, T.A.; Elisseeff, J.H.; Singh, A. Targeted delivery of hyaluronic acid to the ocular surface by a polymer-peptide conjugate system for dry eye disease. Acta Biomater. 2017, 55, 163-171. [CrossRef] [PubMed]

79. Zhu, M.; Wang, J.; Li, N. A novel thermo-sensitive hydrogel-based on poly(N-isopropylacrylamide)/hyaluronic acid of ketoconazole for ophthalmic delivery. Artif Cells Nanomed. Biotechnol. 2018, 46, 1282-1287. [CrossRef] [PubMed] 
80. Mayol, L.; Quaglia, F.; Borzacchiello, A.; Ambrosio, L.; Rotonda, M.I.L. A novel poloxamers/hyaluronic acid in situ forming hydrogel for drug delivery: Rheological, mucoadhesive and in vitro release properties. Eur. J. Pharm. Biopharm. 2008, 70, 199-206. [CrossRef] [PubMed]

81. Cho, K.Y.; Chung, T.W.; Kim, B.C.; Kim, M.K.; Lee, J.H.; Wee, W.R.; Cho, C.S. Release of ciprofloxacin from poloxamer-grafthyaluronic acid hydrogels in vitro. Int. J. Pharm. 2003, 260, 83-91. [CrossRef]

82. Posarelli, C.; Passani, A.; Del Re, M.; Fogli, S.; Toro, M.D.; Ferreras, A.; Figus, M. Cross-Linked Hyaluronic Acid as Tear Film Substitute. J. Ocul. Pharmacol. Ther. 2019, 35, 381-387. [CrossRef]

83. Kabiri, M.; Kamal, S.H.; Pawar, S.V.; Roy, P.R.; Derakhshandeh, M.; Kumar, U.; Hatzikiriakos, S.G.; Hossain, S.; Yadav, V.G. A stimulus-responsive, in situ-forming, nanoparticle-laden hydrogel for ocular drug delivery. Drug Deliv. Transl. Res. 2018, 8, 484-495. [CrossRef] [PubMed]

84. Mahmoudi, S.; Masoomi, A.; Ahmadikia, K.; Tabatabaei, S.A.; Soleimani, M.; Rezaie, S.; Ghahvechian, H.; Banafsheafshan, A. Fungal keratitis: An overview of clinical and laboratory aspects. Mycoses 2018, 61, 916-930. [CrossRef] [PubMed]

85. Huang, H.-Y.; Wang, M.-C.; Chen, Z.-Y.; Chiu, W.-Y.; Chen, K.-H.; Lin, I.C.; Yang, W.-C.V.; Wu, C.-C.; Tseng, C.-L. Gelatinepigallocatechin gallate nanoparticles with hyaluronic acid decoration as eye drops can treat rabbit dry-eye syndrome effectively via inflammatory relief. Int. J. Nanomedicine 2018, 13, 7251-7273. [CrossRef] [PubMed]

86. Kalam, M.A. Development of chitosan nanoparticles coated with hyaluronic acid for topical ocular delivery of dexamethasone. Int. J. Biol. Macromol. 2016, 89, 127-136. [CrossRef]

87. Cavet, M.E.; Harrington, K.L.; Vollmer, T.R.; Ward, K.W.; Zhang, J.-Z. Anti-inflammatory and anti-oxidative effects of the green tea polyphenol epigallocatechin gallate in human corneal epithelial cells. Mol. Vis. 2011, 17, 533-542.

88. McMonnies, C.W. Glaucoma history and risk factors. J. Optom. 2017, 10, 71-78. [CrossRef] [PubMed]

89. Wadhwa, S.; Paliwal, R.; Paliwal, S.R.; Vyas, S.P. Hyaluronic acid modified chitosan nanoparticles for effective management of glaucoma: Development, characterization, and evaluation. J. Drug Target. 2010, 18, 292-302. [CrossRef]

90. Chittasupho, C.; Posritong, P.; Ariyawong, P. Stability, Cytotoxicity, and Retinal Pigment Epithelial Cell Binding of Hyaluronic Acid-Coated PLGA Nanoparticles Encapsulating Lutein. AAPS PharmSciTech 2018, 20, 4. [CrossRef]

91. Liu, H.; Liu, W.; Zhou, X.; Long, C.; Kuang, X.; Hu, J.; Tang, Y.; Liu, L.; He, J.; Huang, Z.; et al. Protective effect of lutein on ARPE-19 cells upon H2O2-induced G2/M arrest. Mol. Med. Rep. 2017, 16, 2069-2074. [CrossRef] [PubMed]

92. Vaishya, R.D.; Khurana, V.; Patel, S.; Mitra, A.K. Controlled ocular drug delivery with nanomicelles. Wiley Interdiscip. Rev. Nanomed. Nanobiotechnol. 2014, 6, 422-437. [CrossRef] [PubMed]

93. Torchilin, V.P. Structure and design of polymeric surfactant-based drug delivery systems. J. Control. Release 2001, 73, 137-172. [CrossRef]

94. Terreni, E.; Chetoni, P.; Tampucci, S.; Burgalassi, S.; Al-Kinani, A.A.; Alany, R.G.; Monti, D. Assembling Surfactants-Mucoadhesive Polymer Nanomicelles (ASMP-Nano) for Ocular Delivery of Cyclosporine-A. Pharmaceutics 2020, 12, 253. [CrossRef] [PubMed]

95. Martens, T.F.; Remaut, K.; Deschout, H.; Engbersen, J.F.J.; Hennink, W.E.; van Steenbergen, M.J.; Demeester, J.; De Smedt, S.C.; Braeckmans, K. Coating nanocarriers with hyaluronic acid facilitates intravitreal drug delivery for retinal gene therapy. J. Control. Release 2015, 202, 83-92. [CrossRef]

96. Osorno, L.L.; Maldonado, D.E.; Whitener, R.J.; Brandley, A.N.; Yiantsos, A.; Medina, J.D.R.; Byrne, M.E. Amphiphilic PLGA-PEGPLGA triblock copolymer nanogels varying in gelation temperature and modulus for the extended and controlled release of hyaluronic acid. J. Appl. Polym. Sci. 2020, 137, 48678. [CrossRef]

97. Mayol, L.; Silvestri, T.; Fusco, S.; Borzacchiello, A.; De Rosa, G.; Biondi, M. Drug micro-carriers with a hyaluronic acid corona toward a diffusion-limited aggregation within the vitreous body. Carbohydr. Polym. 2019, 220, 185-190. [CrossRef] [PubMed]

98. Thakur, S.S.; Shenoy, S.K.; Suk, J.S.; Hanes, J.S.; Rupenthal, I.D. Validation of hyaluronic acid-agar-based hydrogels as vitreous humor mimetics for in vitro drug and particle migration evaluations. Eur. J. Pharm. Biopharm. 2020, 148, 118-125. [CrossRef] [PubMed]

99. Yu, Y.; Lau, L.C.M.; Lo, A.C.-Y.; Chau, Y. Injectable Chemically Crosslinked Hydrogel for the Controlled Release of Bevacizumab in Vitreous: A 6-Month In Vivo Study. Transl. Vis. Sci. Technol. 2015, 4, 5. [CrossRef]

100. Egbu, R.; Brocchini, S.; Khaw, P.T.; Awwad, S. Antibody loaded collapsible hyaluronic acid hydrogels for intraocular delivery. Eur. J. Pharm. Biopharm. 2017, 124, 95-103. [CrossRef]

101. Apaolaza, P.S.; Busch, M.; Asin-Prieto, E.; Peynshaert, K.; Rathod, R.; Remaut, K.; Dünker, N.; Göpferich, A. Hyaluronic acid coating of gold nanoparticles for intraocular drug delivery: Evaluation of the surface properties and effect on their distribution. Exp. Eye Res. 2020, 198, 108151. [CrossRef]

102. Huang, D.; Chen, Y.-S.; Green, C.R.; Rupenthal, I.D. Hyaluronic acid coated albumin nanoparticles for targeted peptide delivery in the treatment of retinal ischaemia. Biomaterials 2018, 168, 10-23. [CrossRef] [PubMed]

103. Huang, D.; Chen, Y.-S.; Rupenthal, I.D. Hyaluronic Acid Coated Albumin Nanoparticles for Targeted Peptide Delivery to the Retina. Mol. Pharm. 2017, 14, 533-545. [CrossRef]

104. Al Qtaish, N.; Gallego, I.; Villate-Beitia, I.; Sainz-Ramos, M.; López-Méndez, T.B.; Grijalvo, S.; Eritja, R.; Soto-Sánchez, C.; Martínez-Navarrete, G.; Fernández, E.; et al. Niosome-Based Approach for In Situ Gene Delivery to Retina and Brain Cortex as Immune-Privileged Tissues. Pharmaceutics 2020, 12, 198. [CrossRef] [PubMed]

105. Taylor, A.W. Ocular Immune Privilege and Transplantation. Front. Immunol. 2016, 7, 37. [CrossRef] [PubMed] 
106. Raia, N.R.; Jia, D.; Ghezzi, C.E.; Muthukumar, M.; Kaplan, D.L. Characterization of silk-hyaluronic acid composite hydrogels towards vitreous humor substitutes. Biomaterials 2020, 233, 119729. [CrossRef] [PubMed]

107. Schramm, C.; Spitzer, M.S.; Henke-Fahle, S.; Steinmetz, G.; Januschowski, K.; Heiduschka, P.; Geis-Gerstorfer, J.; Biedermann, T.; Bartz-Schmidt, K.U.; Szurman, P. The Cross-linked Biopolymer Hyaluronic Acid as an Artificial Vitreous Substitute. Investig. Ophthalmol. Vis. Sci. 2012, 53, 613-621. [CrossRef]

108. Barth, H.; Crafoord, S.; Andréasson, S.; Ghosh, F. A cross-linked hyaluronic acid hydrogel (Healaflow $\left.{ }^{\circledR}\right)$ as a novel vitreous substitute. Graefes Arch. Clin. Exp. Ophthalmol. 2016, 254, 697-703. [CrossRef]

109. Suri, S.; Schmidt, C.E. Cell-Laden Hydrogel Constructs of Hyaluronic Acid, Collagen, and Laminin for Neural Tissue Engineering. Tissue Eng. Part. A 2010, 16, 1703-1716. [CrossRef]

110. Liu, Y.; Ren, L.; Wang, Y. Crosslinked collagen-gelatin-hyaluronic acid biomimetic film for cornea tissue engineering applications. Mater. Sci. Eng. C 2013, 33, 196-201. [CrossRef]

111. Espandar, L.; Bunnell, B.; Wang, G.Y.; Gregory, P.; McBride, C.; Moshirfar, M. Adipose-Derived Stem Cells on Hyaluronic Acid-Derived Scaffold: A New Horizon in Bioengineered Cornea. Arch. Ophthalmol. 2012, 130, 202-208. [CrossRef]

112. Gesteira, T.F.; Sun, M.; Coulson-Thomas, Y.M.; Yamaguchi, Y.; Yeh, L.-K.; Hascall, V.; Coulson-Thomas, V.J. Hyaluronan Rich Microenvironment in the Limbal Stem Cell Niche Regulates Limbal Stem Cell Differentiation. Investig. Ophthalmol. Vis. Sci. 2017, 58, 4407-4421. [CrossRef]

113. Koivusalo, L.; Kauppila, M.; Samanta, S.; Parihar, V.S.; Ilmarinen, T.; Miettinen, S.; Oommen, O.P.; Skottman, H. Tissue adhesive hyaluronic acid hydrogels for sutureless stem cell delivery and regeneration of corneal epithelium and stroma. Biomaterials 2019, 225, 119516. [CrossRef]

114. Lai, J.-Y.; Cheng, H.-Y.; Ma, D.H.-K. Investigation of Overrun-Processed Porous Hyaluronic Acid Carriers in Corneal Endothelial Tissue Engineering. PLoS ONE 2015, 10, e0136067. [CrossRef]

115. Wygladacz, K.A.; Hook, D.J. Visualization of a hyaluronan network on the surface of silicone-hydrogel materials. Clin. Ophthalmol. 2016, 10, 1423-1433. [CrossRef] [PubMed]

116. Singh, A.; Li, P.; Beachley, V.; McDonnell, P.; Elisseeff, J.H. A hyaluronic acid-binding contact lens with enhanced water retention. Cont. Lens Anterior Eye 2015, 38, 79-84. [CrossRef]

117. Deng, X.; Korogiannaki, M.; Rastegari, B.; Zhang, J.; Chen, M.; Fu, Q.; Sheardown, H.; Filipe, C.D.M.; Hoare, T. “Click” ChemistryTethered Hyaluronic Acid-Based Contact Lens Coatings Improve Lens Wettability and Lower Protein Adsorption. ACS Appl. Mater. Interfaces 2016, 8, 22064-22073. [CrossRef]

118. Weeks, A.; Boone, A.; Luensmann, D.; Jones, L.; Sheardown, H. The effects of hyaluronic acid incorporated as a wetting agent on lysozyme denaturation in model contact lens materials. J. Biomater. Appl. 2012, 28, 323-333. [CrossRef] [PubMed]

119. Korogiannaki, M.; Zhang, J.; Sheardown, H. Surface modification of model hydrogel contact lenses with hyaluronic acid via thiol-ene "click" chemistry for enhancing surface characteristics. J. Biomater. Appl. 2017, 32, 446-462. [CrossRef] [PubMed]

120. Scheuer, C.A.; Fridman, K.M.; Barniak, V.L.; Burke, S.E.; Venkatesh, S. Retention of conditioning agent hyaluronan on hydrogel contact lenses. Cont. Lens Anterior Eye 2010, 33, S2-S6. [CrossRef]

121. George, M.; Khong, K.; Maltseva, I. Hyaluronic Acid (HA) Release of HA-Containing Lens Care Solutions with Silicone Hydrogel Lenses. Cont. Lens Anterior Eye 2019, 42, e17-e18. [CrossRef]

122. Scheuer, C.; Rah, M.; Reindel, W. Increased concentration of hyaluronan in tears after soaking contact lenses in Biotrue multipurpose solution. Clin. Ophthalmol. 2016, 10, 1945-1952. [CrossRef] [PubMed]

123. Maulvi, F.A.; Soni, T.G.; Shah, D.O. Extended release of hyaluronic acid from hydrogel contact lenses for dry eye syndrome. J. Biomater. Sci. Polym. Ed. 2015, 26, 1035-1050. [CrossRef] [PubMed]

124. Huang, C.; Zhang, X.; Li, Y.; Yang, X. Hyaluronic acid and graphene oxide loaded silicon contact lens for corneal epithelial healing. J. Biomater. Sci. Polym. Ed. 2020, 1-13. [CrossRef]

125. Wei, N.; Xu, X.; Huang, C.; Cao, L. Hyaluronic Acid-Pluronic ${ }^{\circledR}$ F127-Laden Soft Contact Lenses for Corneal Epithelial Healing: In Vitro and In Vivo Studies. AAPS PharmSciTech 2020, 21, 162. [CrossRef]

126. Ali, M.; Byrne, M.E. Controlled Release of High Molecular Weight Hyaluronic Acid from Molecularly Imprinted Hydrogel Contact Lenses. Pharm. Res. 2009, 26, 714-726. [CrossRef]

127. Weeks, A.; Subbaraman, L.N.; Jones, L.; Sheardown, H. Physical Entrapment of Hyaluronic Acid During Synthesis Results in Extended Release From Model Hydrogel and Silicone Hydrogel Contact Lens Materials. Eye Contact Lens 2013, 39, $179-185$.

128. Desai, A.R.; Maulvi, F.A.; Pandya, M.M.; Ranch, K.M.; Vyas, B.A.; Shah, S.A.; Shah, D.O. Co-delivery of timolol and hyaluronic acid from semi-circular ring-implanted contact lenses for the treatment of glaucoma: In vitro and in vivo evaluation. Biomater. Sci. 2018, 6, 1580-1591. [CrossRef]

129. Maulvi, F.A.; Singhania, S.S.; Desai, A.R.; Shukla, M.R.; Tannk, A.S.; Ranch, K.M.; Vyas, B.A.; Shah, D.O. Contact lenses with dual drug delivery for the treatment of bacterial conjunctivitis. Int. J. Pharm. 2018, 548, 139-150. [CrossRef]

130. Desai, A.R.; Maulvi, F.A.; Desai, D.M.; Shukla, M.R.; Ranch, K.M.; Vyas, B.A.; Shah, S.A.; Sandeman, S.; Shah, D.O. Multiple drug delivery from the drug-implants-laden silicone contact lens: Addressing the issue of burst drug release. Mater. Sci. Eng. C 2020, 112, 110885. [CrossRef]

131. Nguyen, D.; Hui, A.; Weeks, A.; Heynen, M.; Joyce, E.; Sheardown, H.; Jones, L. Release of Ciprofloxacin-HCl and Dexamethasone Phosphate by Hyaluronic Acid Containing Silicone Polymers. Materials (Basel) 2012, 5, 684-698. [CrossRef] [PubMed] 
132. Guidi, G.; Korogiannaki, M.; Sheardown, H. Modification of Timolol Release From Silicone Hydrogel Model Contact Lens Materials Using Hyaluronic Acid. Eye Contact Lens 2014, 40, 269-276.

133. Fiorica, C.; Senior, R.A.; Pitarresi, G.; Palumbo, F.S.; Giammona, G.; Deshpande, P.; MacNeil, S. Biocompatible hydrogels based on hyaluronic acid cross-linked with a polyaspartamide derivative as delivery systems for epithelial limbal cells. Int. J. Pharm. 2011, 414, 104-111. [CrossRef] [PubMed] 